\title{
Soviet Serial Apartment Buildings in Riga Historical Centre Streetscape. 1945-1990
}

\author{
Līva Garkāje, Riga Technical University, Riga, Latvia
}

\begin{abstract}
Today's European historical city centre streetscapes, many of which are designated cultural heritage sites, consist of a mix of urban and architectural housing heritage of different periods, including post World War II period buildings. Nevertheless, knowledge of history of historical centre post-war housing and their artistic and cultural-historical values of this recent past is still insufficient, to a certain degree contradictory, and in some cases even incorrect. This is particularly accurate regarding Modern Movement serial or type Soviet housing in former Soviet republics. This paper presents an ongoing research intended to identify valuable housing streetscape architecture and urban layout traits of post-war period in Latvia (1945-1990) in the environment of historic centre. The goal is to provide specialists in planning and heritage fields with appropriate evaluation criteria and correct know-how material on the theme, as well as general public with cultural historical information considering post-war housing heritage. In this study an example of post-war Modern Movement serial Soviet housing in the historical centre of Riga, the capital city of Latvia, and its protection zone is drawn. The research is based on mapping and auditing streetscapes using Maryland Inventory with this housing typology in historical built environment to identify most common characteristics and qualities of these buildings. The main conclusions are that historical streetscapes do not have significant qualitative differences from historical mixed with post-war housing streetscapes, whereas the quality of streetscapes with dominating post-war modern housing tends to differ from historical streetscapes, as well as has similar shortcomings to those of the large-scale housing block streetscapes.
\end{abstract}

Keywords - Soviet serial apartment buildings, historical centre.

\section{INTRODUCTION}

Post-war city renovation happened in various ways both in the Union of Soviet Socialist Republics (USSR) and elsewhere in Europe. In the southwestern part of the USSR, as well as Eastern European countries under USSR influence it sometimes occurred in spite of the existing urban fabric [1] destructing the remains of historic structures. In northwestern and midwestern parts of the USSR and Western neighbouring countries an overall more historic environment respecting approach was taken retaining the existing historic urban fabric. Regardless reconstruction and city urban fabric development approach [2] in Europe and beyond one finds historic city centres with post-war additions.

Housing, as historically the basic building type in cities, actively participates in shaping streetscapes. Post-war period came with high demand for housing both because of housing stock destruction during the war, and because of the increase of number of city inhabitants. This meant housing renovation in city centres, as well as new housing construction in city periphery. In the USSR even before World War II housing development had taken on the idea of using repeated architectural projects in order to optimize and accelerate housing production. After the war USSR Government Resolution of November 4, 1955, "On Excess Design and Construction" defined this idea into a firm stance stating maximal optimization of housing planning and production, as well as postulating the necessity to industrialize it. It resulted in serial apartment buildings becoming the dominating housing typology in the USSR.

Soviet serial apartment buildings are buildings of the same architectural project appropriated for various locations either in the same vicinity or in different locations. In various sources this typology is called serial [3], type, standardised design [4, 71], prefabricated, mass $[5,10-11]$ or repeated design $[6,264]$ housing. Although during the Stalin era (1922-1955) repeated housing projects were used quite often in the USSR, the most noticeable and criticized is the following post-war modern movement era (1955-1990) when this type of planning was taken to a grander level often using the same building series with the same façade design in large-scale housing estates at maximum varying façade detail colours or the scarce decorations. This type of buildings was used both in large-scale housing estates and elsewhere including pre-war built environment.

Since its inception post-war MoMo Soviet serial apartment housing Soviethas been criticized for visual repetitiveness and poor construction quality. Today in most post-Soviet countries it is complemented with an argument that these buildings symbolize an unwanted regime. Mainly this critique is aimed at buildings in large-scale estates, but due to visual discernibility of each series, it is clearly aimed at buildings of that type in historical urban environments too. In addition, as "much of the $20^{\text {th }}$ century architecture..." these buildings face "... general disapprobation and dislike by the population at large...", limited warranty period close to or at its end, structural problems connected with "...use of new and unproven materials...", as well as "... increasing pace of change in the construction materials industry..." $[7,77]$. These buildings in several post-Soviet countries have become a home for many, as well as a multi-owner property $[8,134]$. It means that currently there is a considerable group of apartment owners who are interested in preserving and maintaining their apartment properties and consequently the buildings housing them.

Today most European countries have at least one city each with a UNESCO listed urban heritage site [9], as well as many more state and local level protected urban architectural heritage zones. In almost all cases they are designated due to valuable edifices built before World War II disregarding those built thereafter. Acknowledging the following period urban contributions to these territories, especially in presently independent former Soviet republics, happens slowly mostly concentrating on seeking for the best examples. On the other hand, background architecture tends to have the biggest impact on overall streetscape quality - be it historical, mixed period or dating to recent decades. Since historical built environment tended to be more 
preserved in northwestern part of the USSR, this research is aimed at assessing the impact of one of the main post-war background architecture elements in the USSR - post-war modernist serial housing, on historical environment streetscape qualities in one of the biggest northwestern USSR historical urban centres Riga city in present day Latvia.

\section{Approaches to Defining Streetscape Qualities}

The quality of streetscapes and structures forming it can be regarded from several points of view. The post-war period architecture is often analysed from socio-historical and art criticism point of view seeking the best or historically important examples, as well as analysing individual buildings and their elements. Such approach is important, as well as internationally defined for evaluating historical heritage [10, 118]. Unfortunately, in most cases it disregards background architecture examples. In addition, various generations of researchers have diverse evaluations depending on their world views and experience or lack thereof with the USSR.

Another approach is sociological analysis to understand user opinions. This method is helpful in determining user point of view at the moment of prompting. Nonetheless, the results of evaluating potential Modern Movement (MoMo) heritage objects with this method deeply depend on the knowledge level and personal interests of the respondents. For instance, many property owners strongly oppose their property designation as heritage because of possible renovation or modification restrictions such status could require. In addition, these opinions can rapidly change with time. If prompted without prior educating general public tends to dislike MoMo style architecture that has not gained any previous positive recognition [7, 77].

The third approach is mapping and auditing streetscape liveability with the researchable typology using measurable criteria derived from the research on human response to urban environment. These measurements tend to provide quantitative data on overall quality level of streetscape, yet they are rarely used when evaluating heritage environment. One of the reasons is each potential heritage object being primarily evaluated individually from the point of view of its uniqueness, artistic quality and historic importance. Serial Soviet apartment buildings by definition are not unique structures, and their artistic quality usually is very critically judged. Although this housing typology is historically important as a manifestation of a grand and to some extent very successful state housing policy, with few exceptions this does not serve as sufficient argumentation for seriously considering these buildings as potential heritage objects. Nonetheless, such buildings have impact on historic streetscape quality. What is this impact? Does this typology diminish historical streetscape quality? What elements contribute to that?

\section{Research Methodology}

For studying the impact of the post-war Soviet modernist serial apartment buildings on the historic centre streetscape the historical centre of Latvian capital city Riga and its protection zone was chosen. One of the reasons for such choice is that Riga was and still is the biggest city in the Baltic states with a rich $19^{\text {th }}$ century and early $20^{\text {th }}$ century historic urban fabric of $1-2$ story timber and dominantly 5-6 storey masonry buildings in its central part outside its medieval Old Town. During the Soviet period (1945-1990), Riga was the industrial and military centre of the Baltic region attracting immigrant workers and extensive new housing construction boom for them. In 1997, the historical centre of Riga was designated as the UNESCO world heritage site for its "... medieval and later period urban planning structure..., as well as the quantity and quality of Art Nouveau architecture... and the $19^{\text {th }}$ century wooden architecture..." [11].

To understand how many Soviet serial apartment buildings were built in the territory under research, a mapping method was used. It was accomplished using satellite and street view (Google Maps), as well as orthographic or Birdview aerial photographs (Bing Maps) visually identifying serial apartment buildings. It was possible because serial Soviet serial housing has a distinct well recognizable visual appearance. Modern movement principles of pure form of Soviet period housing appearance were mainly influenced by load-bearing construction materials used. From 1955 till early 1960s silicate brick was the main wall material; from the 1960s to 1991 concrete panels were used; from mid 1970s to 1991 mixed brick and concrete panel constructions appeared. Thus, taking into account construction materials as an indicator of visual variety, series type, as well as construction period, the selected buildings were divided into 3 groups: 1) brick buildings (both plastered and with exposed brick facades); 2) concrete panel buildings; 3) mixed material buildings (bricks + concrete panels). Based on the results obtained by preliminary mapping (Fig. 1) a detailed case study area with the biggest variety of serial housing (Fig. 2) was chosen assuming that such approach would produce the largest variety of results.

In order to select street blocks for measuring, the case study area was mapped discerning pre-war urban fabric, post-war Stalin era buildings, post-war modern style Soviet serial housing, postwar individual design housing, other Soviet era buildings and buildings constructed after 1991 (Fig. 3).

Following the mapping results, 4 street blocks with mixed historical and post-war Soviet serial apartment buildings, 4 street blocks with solely post-war Soviet built environment (Fig. 4), as well as 4 reference street blocks with almost exclusively pre-war and occasional Stalin period buildings with analogous historic building urban layout and scale to the detailed case study area were chosen (Fig. 5) for measuring streetscape quality criteria reference values.

Since the detailed case study area was in the protection zone of the historic centre, which has a higher timber building proportion and greater building height variety, the reference streetscapes were chosen in the protection zone area as well.

Liveability is defined by criteria that are used to measure human attraction to an urban space $[12,149]$. Depending on the spatial scale, it can be divided into three levels of analysis: $m i$ croscale, mesoscale and macroscale. Microscale level includes 


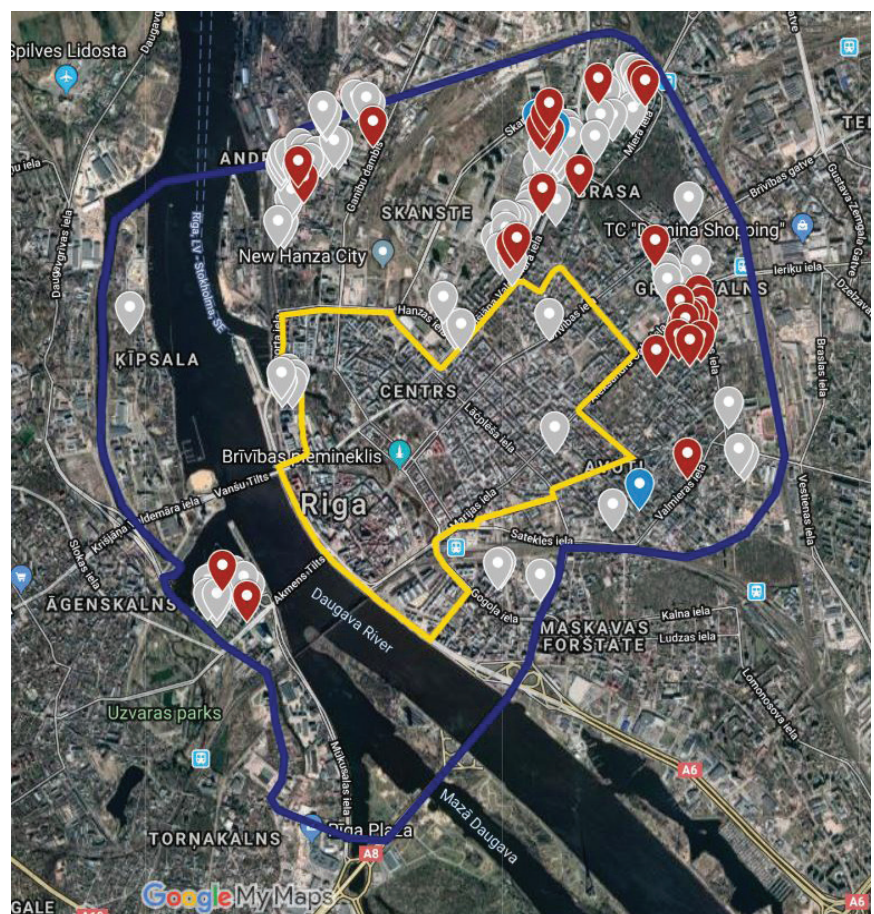

Fig. 1. Mapping results of serial apartment buildings in Riga historical centre and its protection zone. Dark blue line - protection zone of historical centre of Riga; yellow line - historical centre of Riga; grey pinpoints - brick serial apartment buildings; blue pinpoints - concrete panel serial apartment buildings; red pinpoints - mixed material serial apartment buildings [Figure: Līva Garkāje, Anna Bumbiere, Alisa Mazore, Jana Voiciša, 2019].

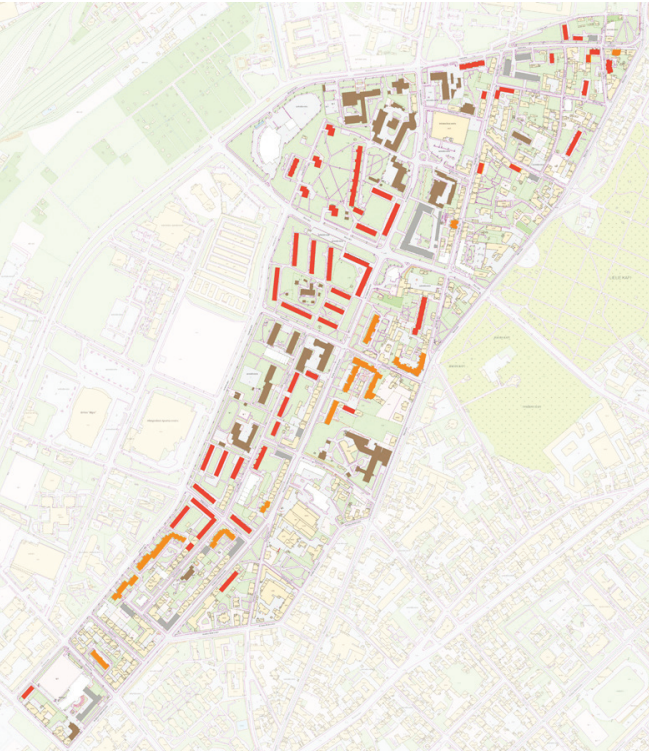

Fig. 3. Urban fabric of case study area. Yellow - pre-war urban tissue; grey Stalin era style apartment buildings (1945-1955); red - post-war modern Sovie serial apartment buildings; orange - individual design Soviet apartment buildings; white - buildings built after 1991 [Figure: Līva Garkāje, 2019].

analysis of human scale, complexity, imageability (the quality of a place that makes it distinct, recognizable, and memorable $[13,9])$, transparency (the degree to which people can see or perceive human activity or what lies beyond the edge of a street or other public space $[14,78])$, and coherence $[15,500]$.

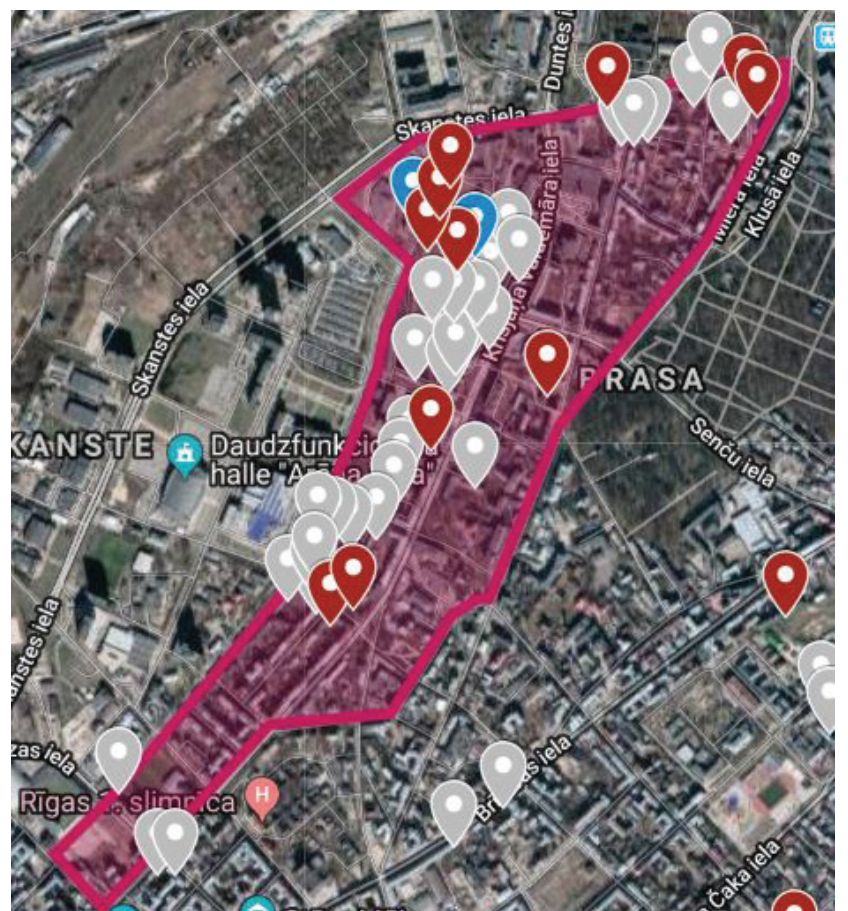

Fig. 2. Further case study area: serial housing cluster between Vesetas, Skanstes, Upes, Invalīdu, Miera, Aristīea Briāna, Krišsjāna Valdemāra and Emiḷa Melngail̦a Streets [Figure: Līva Garkāje, Anna Bumbiere, Alisa Mazore, Jana Voiciša, 2019].

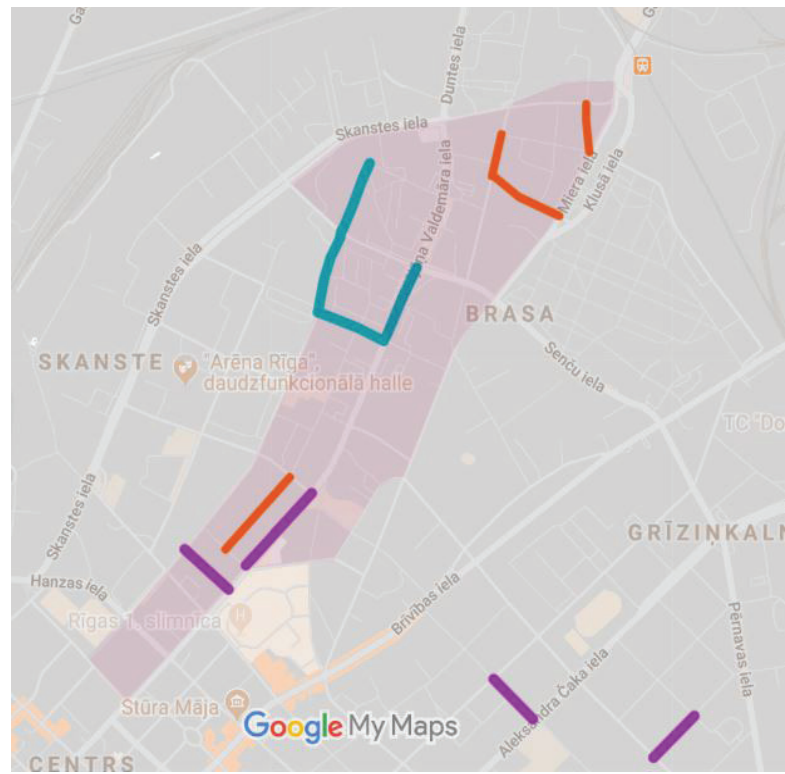

Fig. 4. Mixed and post-war urban built environment street blocks chosen for measuring streetscape quality. Violet - historic streetscape blocks for reference measurements; orange - mixed urban fabric street blocks; turquoise - post-war MoMo street blocks [Figure: Līva Garkāje using Google Maps, 2019].

Mesoscale deals with analysing enclosure (the degree to which streets and other public spaces are visually defined by buildings, walls, trees, and other vertical elements [16, 29]), and some aspects of human scale (size, texture, and articulation of physical elements that match the size and proportions of humans and correspond to the speed at which humans walk [17,9]), whereas 
HISTORIC
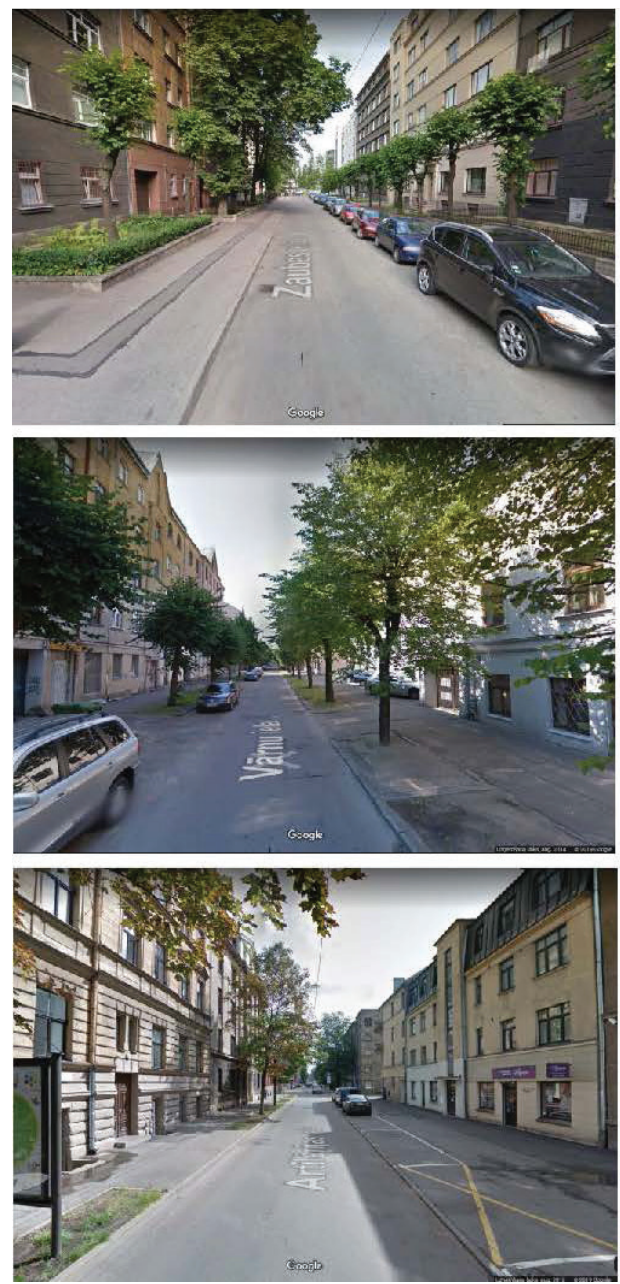

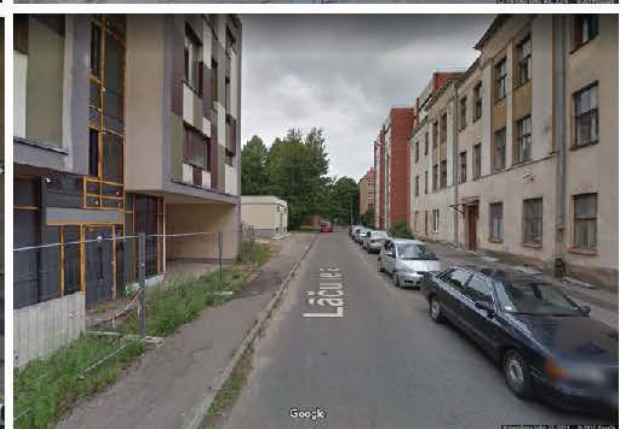

MIXED
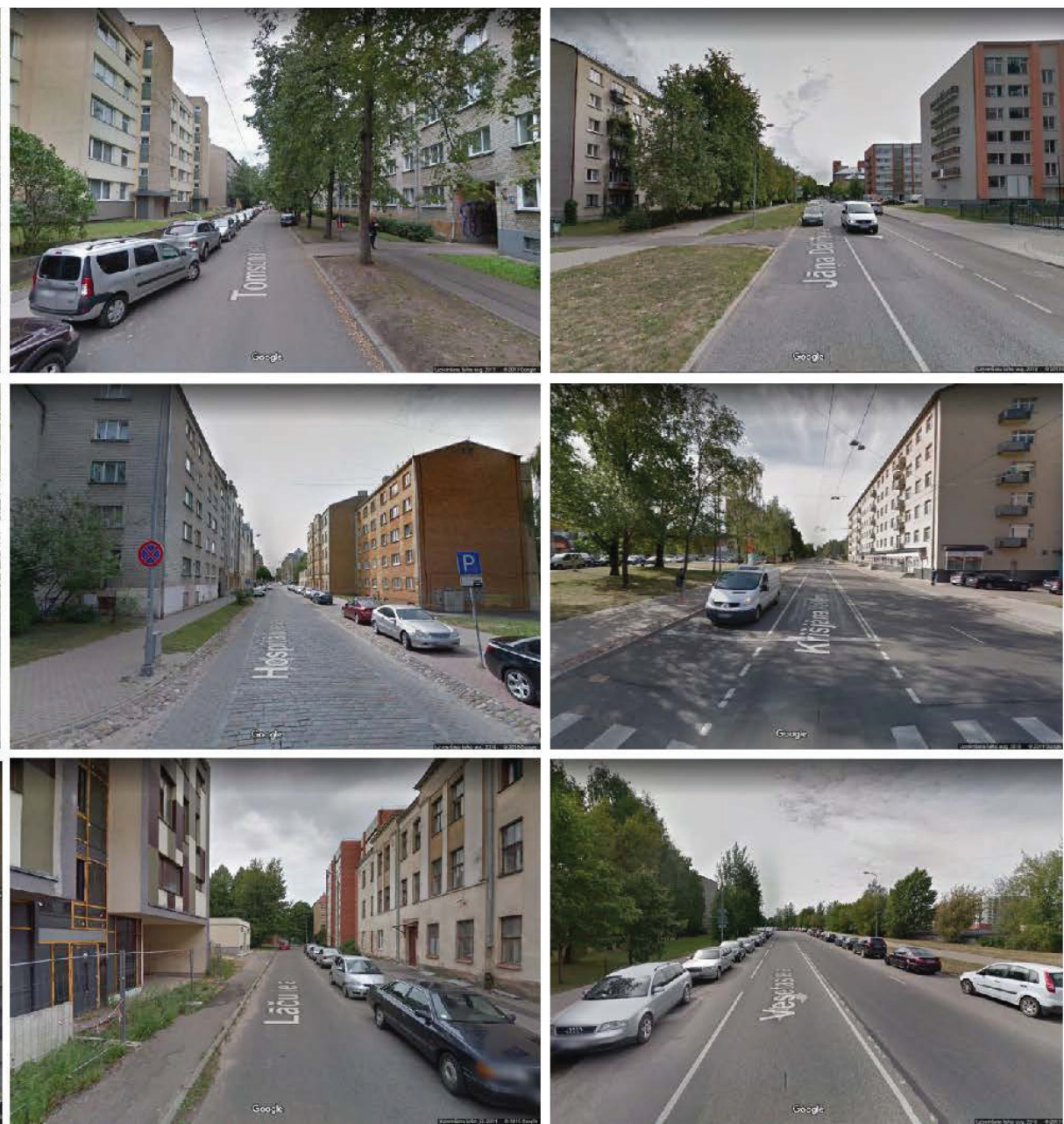

Fig. 5. Google Street View screenshots of the chosen historic (left column), mixed (middle column), and post-war (right column) streetscapes [Google, 2019].

macroscale is concerned with accessibility [17,90] and mobility $[12,150]$. This research deals with mesoscale and microscale level measurements concerning in situ experience of post-war modernist Soviet serial housing in historical environment. To assess streetscape quality in the detailed case study area this research uses Maryland Inventory developed by Ewing et al., which is a well-tested streetscape audit method for measuring [17, 99-135]. In this method, each of the urban quality parameters has several operationalized quantitative parameters. For imageability they are: 1) number of accessible courtyards, plazas, parks and gardens; 2) number of visible/prominent major landscape features; 3) proportion of historic buildings in the block; 3) number of buildings with identifiers (e. g. informative signs); 4) whether there is presence of outdoor dining in the block; 5) number of people on the street while surveying it; 6) noise level on the street. Enclosure is defined by 1) number of long sight lines; 2) proportion of street wall; 3) proportion of visible sky ahead and across the street; 4) presence of trees. Human scale is operationalized by 1) number of long sight lines; 2) proportion of street level windows against the length of street block; 3 ) average building height; 4) number of small planters; 5) number of street furniture pieces and other items; 6) number of outdoor dining tables in the block; 7) number of lights on buildings. Transparency is measured by 1) the proportion of street level windows against the length of street block; 2) calculating street wall proportion, and 3) counting buildings of active use (parks, stores, restaurants, attached apartment-style residential building, hospitals, schools, etc.). Finally, complexity is estimated by 1) counting the visible buildings in the block; 2) counting basic and building accent colours separately; 3) noting the presence of outdoor dining; 4) counting pieces of public art, and 5) counting the number of people on the street while surveying it. Following the results of research on using digital tools like Google Street View [18] and GIS data [19] in streetscape quality measures it was decided to use these tools for the research. 


\section{Results}

Mapping of the Soviet serial apartment buildings yielded 128 addresses and indicated areas of the biggest concentration, as well as variety. Riga historical centre proved to have very few serial apartment buildings, whereas its protection zone has 4 zones of high serial housing concentration built within pre-war built environment of various density (Fig. 1). The greatest variety of serial apartment buildings was found in the northern part of the protection zone between Miera and Vesetas streets. Brick buildings of the early period of post-war modernism style proved to be the most numbered yielding 94 addresses, mixed material buildings were found at 30 addresses, whereas panel buildings were the fewest - only 4 . This clearly marks historical centre reconstruction waves - the most active during 1950s and early 1960s when brick construction load bearing longitudinal walls were used; the least active - period between mid 1960s and mid 1970 s, which was the time when large scale housing estates consisting of concrete panel serial apartment buildings started to be constructed in city's periphery. In addition, the small number of concrete panel buildings in the city's central part may be explained by unwillingness to develop housing of lower construction quality, which concrete panel apartment buildings tended to be in the area where more privileged citizens usually got housing. In the 1970s, housing reconstruction in Riga's central part resumed building variations of series 103 with load-bearing red brick partition walls with exposed wall ends in the facades and concrete or sandwich panels with timber, metal or tiling finish.

Historiographical analysis of the detailed case study area (Fig. 3) showed a variety of urban layouts of post-war modernist serial apartment buildings. In the streets with pre-war urban fabric, the early and late period buildings tend to be placed parallel to the street with approx. 3-4 $\mathrm{m}$ indent from the historic facade line. In blocks where no pre-war urban tissue was or it had been cleared to build new structures early and mid-period housing tends to be organized following simple free urban plan schemes. In new housing blocks mixed material serial apartment buildings tend to be aligned to the existing street grid and consequently to perimetral urban plan scheme.

Streetscape imageability measurements (Table I) showed mostly insignificant difference between historical, mixed and post-war urban fabric streetscapes. In all measured streetscapes 4-5 accessible courtyards, plazas, parks or gardens were detected. None of the street blocks had any visible or prominent major landscape features. The only considerable difference between all 3 streetscape types was in the building with identifier number. The survey showed that the bigger post-war housing percentage on the street the less identifiers the buildings have. This displays an overall tendency of Soviet typologies with few exceptions to separate various functions in independent buildings. Unfortunately, in case of housing it resulted in diminishing streetscape quality around it as the ground floor level tended to be made

TABLE I

Average Measurements of Imageability [Līva Garkāje, 2019].

\begin{tabular}{|c|c|c|c|c|c|c|c|c|c|}
\hline Score s & sheet of measur & ng urban & sign qualities & auditor: & Livva Gark & & HISTORIC & HISTORIC MIXED & POST-WAR \\
\hline $\begin{array}{l}\text { date \& } \\
\text { time: }\end{array}$ & $\begin{array}{l}\text { 14.-15.10.20 } \\
\text { Google Street }\end{array}$ & $\begin{array}{l}\text { ( }(08.20 \\
\text { iew) }\end{array}$ & 07.2014. from & weather/temp: & $\begin{array}{l}\text { sunny/clou } \\
20 \mathrm{deg}{ }^{\circ} \mathrm{C}\end{array}$ & $/+15 \ldots$ & AVERAGE & AVERAGE & AVERAGE \\
\hline Step \# & Quality & Step & & Process & Direction & Study area & Recorded value & Recorded value & Recorded value \\
\hline Image & ability & & & & & & & & \\
\hline 1.1 & Imageability & $\begin{array}{l}\text { accessib } \\
\text { plazas, }\end{array}$ & $\begin{array}{l}\text { courtyards, } \\
\text { ks and gardens }\end{array}$ & count & both sides & within & 5 & 4 & 5 \\
\hline 1.2 & Imageability & $\begin{array}{l}\text { visible/1 } \\
\text { landsca }\end{array}$ & $\begin{array}{l}\text { minent major } \\
\text { eeatures }\end{array}$ & count & both sides & beyond & $\mathbf{0}$ & $\mathbf{0}$ & $\mathbf{0}$ \\
\hline 1.4 & Imageability & building & vith identifiers & count & both sides & within & 8 & 4 & 3 \\
\hline 1.5 & Imageability & $\begin{array}{l}\text { building } \\
\text { nonrects }\end{array}$ & $\begin{array}{l}\text { vith } \\
\text { ular shapes }\end{array}$ & count & both sides & within & 13 & 10 & 10 \\
\hline 1.6 & Imageability & presenc & atdoor dining & $\mathrm{Y}=1 / \mathrm{N}=0$ & your side & within & $\mathbf{0}$ & $\mathbf{0}$ & $\mathbf{0}$ \\
\hline 1.7 & Imageability & people & walk- through 1 & walk-through & your side & within & 5 & 5 & 4 \\
\hline 1.8 & Imageability & $\begin{array}{l}\text { noise le } \\
\text { loudest) }\end{array}$ & $(1-5 ; 5$ is the & est. (1-5) & both sides & within & 3 & 3 & 3 \\
\hline
\end{tabular}


without publicly accessible functions. In terms of the amount of nonrectangular building shapes the research showed that although historic streetscapes had a bit higher number of nonrectangular buildings, the mixed and post-war housing streetscapes still had a significant number of nonrectangular buildings. It was either because of being equipped with balconies or loggias, or because of overlapping building shapes.

In terms of enclosure (Table II) mixed streetscapes proved to have the same indicator values as the historic streetscapes, whereas post-war streetscapes had a higher ratio of long sight lines and proportion of visible sky due to free urban plan building layouts. Consequently, the proportion of street wall in post-war streetscapes was two to three times smaller than in mixed and historic streetscapes because the post-war buildings are placed farther than $3 \mathrm{~m}$ from sidewalks, and to street wall contributing vegetation (height $>1.5 \mathrm{~m}$ ) is scattered and mainly facing buildings instead of facing the gaps between them.

Similar to enclosure measurements human scale factors (Table III) proved to be rather alike for historic and mixed streetscapes, while post-war streetscapes had most values different. Lower values were measured for eye level window proportion, small planter and light on the buildings number, whereas the building height tended to be bigger, as well as street furniture and other street item number. The lesser window proportion indicates both that in free urban plan housing schemes ground floor level is not used for street level retail functions but for apartments in-

TABLE II

Average Enclosure Measurements [Līva Garkāje, 2019].

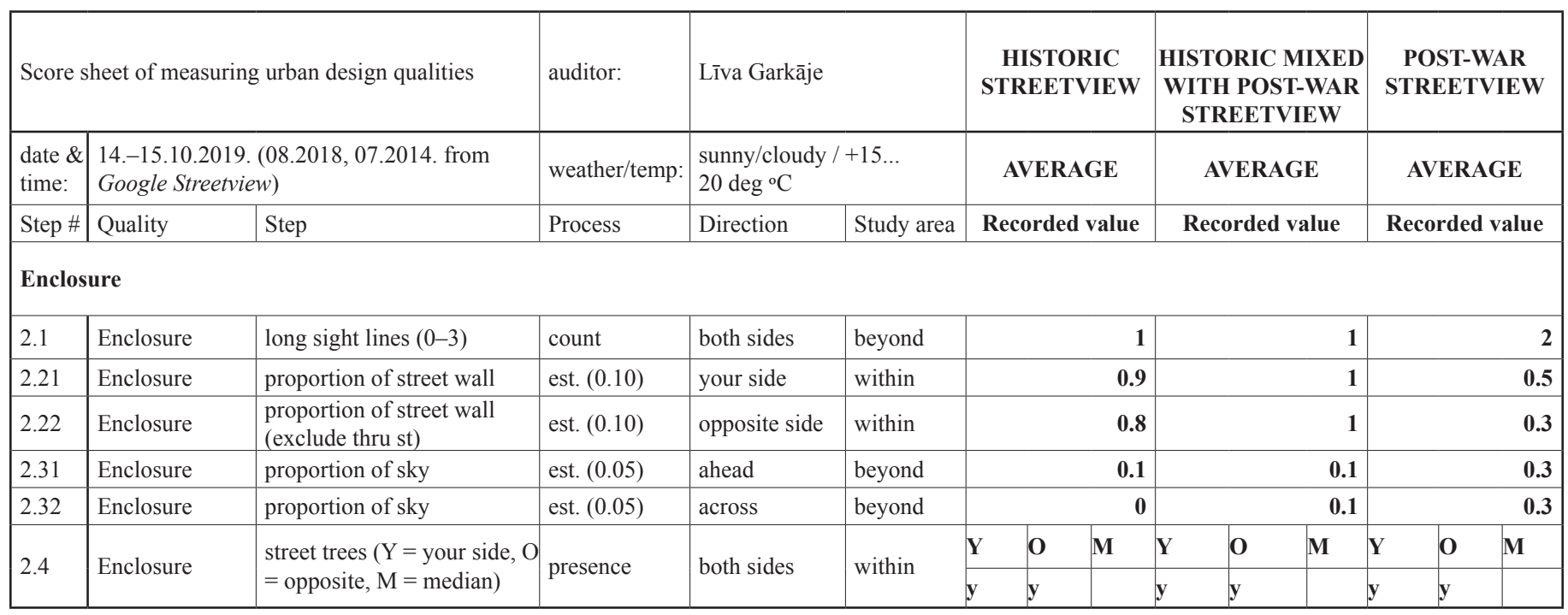

TABLE III

Average Human Scale Measures [Līva Garkāje, 2019].

\begin{tabular}{|c|c|c|c|c|c|c|c|c|}
\hline \multicolumn{3}{|c|}{ Score sheet of measuring urban design qualities } & \multirow{3}{*}{$\begin{array}{l}\text { auditor: } \\
\text { weather/temp: } \\
\text { Process } \\
\end{array}$} & \multirow{2}{*}{\multicolumn{2}{|c|}{\begin{tabular}{|l} 
Līva Garkāje \\
$\begin{array}{l}\text { sunny/cloudy } /+15 \ldots \\
20 \text { deg }{ }^{\circ} \mathrm{C}\end{array}$
\end{tabular}}} & \multirow{3}{*}{$\begin{array}{c}\text { HISTORIC } \\
\text { STREETVIEW } \\
\text { AVERAGE } \\
\text { Recorded value }\end{array}$} & \multirow{3}{*}{$\begin{array}{c}\text { HISTORIC } \\
\text { MIXED WITH } \\
\text { POST-WAR } \\
\text { STREETVIEW } \\
\text { AVERAGE } \\
\text { Recorded value }\end{array}$} & \multirow{3}{*}{$\begin{array}{c}\text { POST-WAR } \\
\text { STREETVIEW } \\
\text { AVERAGE } \\
\text { Recorded value }\end{array}$} \\
\hline $\begin{array}{l}\text { date } \\
\& \\
\text { time: }\end{array}$ & \multicolumn{2}{|c|}{$\begin{array}{l}\text { 14.-15.10.2019. (08.2018, 07.2014. from } \\
\text { Google Streetview) }\end{array}$} & & & & & & \\
\hline Step \# & Quality & Step & & Direction & Study area & & & \\
\hline \multicolumn{9}{|c|}{ Human Scale } \\
\hline 3.1 & Human Scale & long sight lines $(0-3)$ & --- & both sides & beyond & 1 & 1 & 2 \\
\hline 3.2 & Human Scale & $\begin{array}{l}\text { proportion of window } \\
\text { (street-level)/ block }\end{array}$ & est. $(0.10)$ & your side & within & 0.2 & 0.2 & 0.1 \\
\hline 3.3 & Human Scale & building height & average & your side & within & 15 & 16 & 23 \\
\hline 3.4 & Human Scale & small planters & count & your side & within & 2 & 1 & $\mathbf{0}$ \\
\hline 3.51 & Human Scale & $\begin{array}{l}\text { pieces of street furniture \& } \\
\text { other street items }\end{array}$ & count & your side & within & 18 & 17 & 22 \\
\hline 3.52 & Human Scale & outdoor dining tables & count & your side & within & $\mathbf{0}$ & $\mathbf{0}$ & $\mathbf{0}$ \\
\hline 3.53 & Human Scale & $\begin{array}{l}\text { lights on buildings (not } \\
\text { more than } 10 \mathrm{ft} \text {. high) }\end{array}$ & count & your side & within & 7 & 4 & $\mathbf{0}$ \\
\hline
\end{tabular}


stead, and that apartment windows are elevated above eye level in order to maintain inhabitant privacy. In addition, the entrances to the buildings tend to be placed on the courtyard side or above street level on the street side. Thus, these streetscapes do not have any to entrances corresponding street level building lights. Post-war housing schemes tend to have considerable amount of green territories around them. Therefore, it is understandable that in such zones small planters are scarce. Instead they have flowerbeds maintained by inhabitants, as well as trees and shrubs. In addition, these territories tend to have street furniture that is characteristic to parks (benches, garbage bins, pole lights, children playgrounds), whereas in historic and mixed streetscapes such items were recorded less because of the comparatively dense street wall.

Transparency measures (Table IV) relied largely on factor values (street level window and street wall proportion) discussed in previous paragraphs. These values are lower for post-war streetscapes comparing to mixed and historic ones due to urban layout and ground floor planning and level height differences. In contrast, all three streetscape types have high active use, which is defined by building functions that in all three streetscape types are fairly similar with dominating housing function complemented with occasional educational, office or retail building or its section. All of these functions according to the method used are considered active.

Complexity parameters (Table V) proved to be quite similar for all three streetscape types with a small value decline for mixed and post-war streetscapes. In terms of building number this can be explained with historic streetscapes being more densely built up in perimetral urban layout schemes comparing to mixed streetscapes. Whereas post-war streetscapes have less but bigger size buildings ordered in free urban plan schemes deeper in the street block. Decline in basic and accent building colour number for post-war streetscapes is connected to these streetscapes being formed by Soviet serial apartment buildings with maximum 3 different series within the same street block. The buildings of the same series tend to have the same facade base and accent colours. For all streetscape types one of the contributors to accent colour number was variety of window frame colours within the same building, which can be explained by individual window replace-

TABLE IV

Average Transparency Measures [Līva Garkāje, 2019].

\begin{tabular}{|c|c|c|c|c|c|c|c|c|}
\hline \multicolumn{3}{|c|}{ Score sheet of measuring urban design qualities } & \multirow{3}{*}{$\begin{array}{l}\text { auditor: } \\
\text { weather/temp: } \\
\text { Process }\end{array}$} & \multirow{2}{*}{\multicolumn{2}{|c|}{\begin{tabular}{|l} 
Līva Garkāje \\
sunny/cloudy $/+15 \ldots .20 \mathrm{deg}{ }^{\circ} \mathrm{C}$
\end{tabular}}} & \multirow{3}{*}{$\begin{array}{c}\text { HISTORIC } \\
\text { STREETVIEW } \\
\text { AVERAGE } \\
\text { Recorded value }\end{array}$} & \multirow{3}{*}{$\begin{array}{c}\text { HISTORIC } \\
\text { MIXED WITH } \\
\text { POST-WAR } \\
\text { STREETVIEW } \\
\text { AVERAGE } \\
\text { Recorded value }\end{array}$} & \multirow{3}{*}{\begin{tabular}{|c|} 
POST-WAR \\
STREETVIEW \\
AVERAGE \\
Recorded value
\end{tabular}} \\
\hline $\begin{array}{l}\text { date } \& \\
\text { time: }\end{array}$ & \multicolumn{2}{|c|}{$\begin{array}{l}\text { 14.-15.10.2019. (08.2018, } 07.2014 . \\
\text { from Google Streetview) }\end{array}$} & & & & & & \\
\hline Step \# & Quality & Step & & Direction & Study area & & & \\
\hline \multicolumn{9}{|c|}{ Transparency } \\
\hline 4.1 & Transparency & $\begin{array}{l}\text { proportion of window } \\
\text { (street-level)/ block }\end{array}$ & --- & your side & within & 0.2 & 0.2 & 0.1 \\
\hline 4.2 & Transparency & proportion of street wall & -- & your side & within & 0.9 & 0.9 & 0.5 \\
\hline 4.3 & Transparency & $\begin{array}{l}\text { proportion of active use/ } \\
\text { block }\end{array}$ & est. (0.10) & your side & within & 0.9 & 0.9 & 0.9 \\
\hline
\end{tabular}

TABLE V

Average measures of complexity [Līva Garkāje, 2019].

\begin{tabular}{|c|c|c|c|c|c|c|c|c|c|}
\hline \multicolumn{4}{|c|}{ Score sheet of measuring urban design qualities } & \multirow{3}{*}{\begin{tabular}{|l|} 
auditor: \\
$\begin{array}{l}\text { weather/ } \\
\text { temp: }\end{array}$ \\
Process \\
\end{tabular}} & \multirow{2}{*}{\multicolumn{2}{|c|}{$\begin{array}{l}\text { Lìva Garkāje } \\
\text { sunny/cloudy } /+15 \ldots 20 \mathrm{deg}{ }^{\circ} \mathrm{C}\end{array}$}} & \multirow{3}{*}{$\begin{array}{c}\text { HISTORIC } \\
\text { STREETVIEW } \\
\text { AVERAGE } \\
\text { Recorded value }\end{array}$} & \multirow{3}{*}{$\begin{array}{c}\text { HISTORIC } \\
\text { MIXED WITH } \\
\text { POST-WAR } \\
\text { STREETVIEW } \\
\text { AVERAGE } \\
\text { Recorded value }\end{array}$} & \multirow{3}{*}{\begin{tabular}{|c|} 
POST-WAR \\
STREETVIEW \\
AVERAGE \\
Recorded value
\end{tabular}} \\
\hline $\begin{array}{l}\text { date \& } \\
\text { time: }\end{array}$ & \multicolumn{3}{|c|}{$\begin{array}{l}\text { 14.-15.10.2019. (08.2018, 07.2014. from } \\
\text { Google Streetview) }\end{array}$} & & & & & & \\
\hline Step \# & Quality & Step & & & Direction & Study area & & & \\
\hline \multicolumn{10}{|c|}{ Complexity } \\
\hline 5.1 & Complexity & \multicolumn{2}{|c|}{ buildings } & count & both sides & within & 14 & 13 & 10 \\
\hline 5.21 & Complexity & \multicolumn{2}{|c|}{ basic building colors } & count & both sides & within & 5 & 5 & 4 \\
\hline 5.22 & Complexity & \multicolumn{2}{|c|}{ accent colors } & count & both sides & within & 8 & 7 & 6 \\
\hline 5.3 & Complexity & \multicolumn{2}{|c|}{ presence of outdoor dining } & -- & your side & within & 0 & 0 & 0 \\
\hline 5.4 & Complexity & \multicolumn{2}{|c|}{ pieces of public art } & count & both sides & within & 2 & 3 & 2 \\
\hline 5.51 & Complexity & people & walk- through 1 & --- & your side & within & 5 & 5 & 4 \\
\hline
\end{tabular}


ments or repainting for each apartment. In case of all streetscape types the public artwork type was graffiti. All of them could be judged to be of an arbitrary and therefore temporary character subculture specific writings placed on the plinth level of buildings sooner or later to be erased or painted over.

\section{FINDINGS}

Riga historical centre has only 4 post-war modern Soviet serial apartment buildings, whereas its protection zone has approximately 124 buildings of this type. They tend to be concentrated in 4 neighbourhoods. The neighbourhood with the biggest variety and number of serial apartment buildings is in the northeastern part of the protection zone between Miera and Vesetas streets.

The buildings are placed either within historic urban fabric following its logic or in separate clusters following free urban plan logic characteristic to large scale housing schemes. Both free plan and perimetral urban schemes were used. In the detailed research area free plan schemes were mostly built in separate historic building free blocks. When facing historic urban tissue, these blocks tend to adapt semi-perimetral form. Soviet serial apartment buildings incorporated among historical buildings tend to follow perimetrical schemes sometimes stepping back 3-4 $\mathrm{m}$ from the wall line of historical street.

Using Maryland inventory of design qualities (MIDQ) method comparing 4 historic, 4 mixed (historic+ post-war) and 4 post-war block streetscapes proved that mixed and historic streetscapes did not have significant quality differences from the historical ones, whereas examined post-war streetscapes tended to have smaller street wall and street level window ratio, as well as smaller amount of identifiers displaying poorer quality level of each urban block framing street streetscape common in large-scale estates.

Maryland inventory of design qualities criteria method has a good potential in providing an overview of urban design quality measures including building street walls. The method concentrates on counting elements contributing to overall environment detailing. Meanwhile it does not provide a way of assessment of each element design and deterioration level. As a result, in order to gain a comprehensive view or microscale a more detailed analysis is necessary.

\section{Conclusions}

Post-war MoMo Soviet serial apartment buildings in the researched territory of Riga historical centre and its protection zone proved to serve background architecture function in mixed streetscapes well by blending in historic urban tissue without substantially diminishing its quality. Since Riga city centre has an abundance of housing series (for example series 316; 318, and 303) that were used not only in Latvia but also in its neighbouring Baltic states Estonia and Lithuania, the results of this research can serve as a reference for research on mixed historic streetscapes and serial housing architectural qualities in other Baltic states too.

Architectural elements of serial housing contributing to maintaining historic streetscape quality are nonrectangular shapes (nonrectangular roof and shape of the building, balconies, loggias, façade detailing and finishing variety), presence of street level glazed surfaces, as well as facade colouring that visually does not contrast with and does not significantly outnumber the colour variety of the surrounding historic buildings. Therefore, when evaluating architectural and heritage status of these buildings, as well as defining elements to preserve or enhance in case of renovation, variety of abovementioned elements, their rhythm and detailing richness should be taken into consideration.

The researched post-war streetscape blocks are rather pure examples of relatively small large-scale housing urban schemes and therefore have a certain cultural value. In the same time, as part of historical centre protection zone their streetscapes facing historical streets could be improved by enhancing street wall ratio both by supplementing vegetational street wall elements (at least $1.5 \mathrm{~m}$ high plants) and by introducing $1-1.5$ story high temporary of permanent retail or other public function structures along the sidewalks in the zones between sidewalk and apartment buildings where possible.

\section{REFERENCES}

1. Jerliu, F., Navakazi, V. The Socialist Modernization of Prishtina: Interrogating Types of Urban and Architectural Contributions to the City. Mesto a dejiny, 2018, Vol. 7, No. 2, pp. 55-74.

2. Vilkončius, E. Soviet Modernism in the Historic Context. The Cases of Vilnius and Panevezžys City Centers. Art History \& Criticism, 2017, Vol. 13, pp. 58-75. ISSN 1822-4555.

3. Meuser, P. Serial housing construction in the Soviet Union: an architectural-historical approach. Soviet modernism 1955-1991. Unknown history. Zurich: Park Books, 2012, pp. 273-283. ISBN 978-3-906027-14-2.

4. Dremaite, M. The Exceptional Design of Large Housing Estates in the Baltic Countries. Housing Estates in the Baltic Countries. The Legacy of Central Planning in Estonia, Latvia and Lithuania. Springer, Cham, 2019 pp. 71-93 https://doi.org/10.1007/978-3-030-23392-1 4

5. Meuser, P., Zadorin, D. Towards a Typology of Soviet Mass Housing Prefabrication in the USSR 1955-1991. Berlin: DOM Publishers, 2015. 456 p. ISBN 978-3-86922-329-2.

6. Zarecor, K. E. Architecture in Eastern Europe and the Former Soviet Union. A Critical History of Contemporary Architecture, 1960-2010. London: Routledge, 2014, pp. 255-274.

7. Nypan, T. The Challenges Posed by the Eu Legislation for the Conservation of 20th Century Architecture. Law and the Conservation of 20th Century Architecture. Cinisello Balsamo: Mendrisio Academy Press / Silvana Ed itoriale, 2004, p 77.

8. Tsenkova, S., Turner, B. The Future of Social Housing in Eastern Europe: Reforms in Latvia And Ukraine. European Journal of Housing Policy. 2004 Vol. 4, No. 2, pp. 133-149. https://doi.org/10.1080/1461671042000269001

9. World Heritage List [online]. United Nations Educational, Scientific and Cultural Organization [cited 12/18/2019]. https://whc.unesco.org/en/list/?search $=\&$ themes $=11 \&$ type $=$ cultural\&order $=$ country

10. The Nara Document on Authenticity (1994). International Council on Monuments and Sites. International charters for conservation and restoration $=$ Chartes internationales sur la conservation et la restauration $=$ Cartas internacionales sobre la conservación y la restauración: ICOMOS, 2004. 179 p. ISBN 3874906760.

11. Historic Centre of Riga [online]. United Nations Educational, Scientific and Cultural Organization [cited 12/18/2019]. https://whc.unesco.org/en/ list/852/

12. Harvey, C., Aultman-Hall, L. Measuring Urban Streetscapes for Livability: A Review of Approaches. The Professional Geographer, 2016. Vol. 68, No. 1, pp. 149-158. https://doi.org/10.1080/00330124.2015.1065546

13. Lynch, K. The Image of the City. Cambridge, MA: MIT Press. 1960. 194 p

14. Ewing, R., Handy, S. Measuring the Unmeasurable: Urban Design Qualities Related to Walkability. Journal of Urban Design, 2009. Vol. 14, No. 1, pp. 65-84. https://doi.org/10.1080/13574800802451155

15. Nasar, J. L. The Effect of Sign Complexity and Coherence on the Perceived Quality of Retail Scenes. Journal of the American Planning Association, 1987. Vol. 53, No. 4, pp. 499-509. https://doi.org/10.1080/01944368708977139 
16. Cullen, G. The Concise Townscape. Van Nostrand Reinhold Company, 1961. 199 p. ISBN 0442217706.

17. Ewing, R., Clemente, O., Neckermaan, K.M., Purciel-Hill, M., Quinn, J.W., Rundie, A. Measuring Urban Design : Metrics of Livable Places. Washington, DC: Island Press/Center for Resource Economics, 2013. 188 p. ISBN $978-1-59726-367-2$

https://doi.org/10.5822/978-1-61091-209-9

18. Steinmetz-Wood, M., Velauthapillai, K., O'Brien, G., Ross, A.N.

Assessing the micro-scale environment using Google Street View : the Virtual Systematic Tool for Evaluating Pedestrian Streetscapes (Virtual-STEPS). BMC Public Health, 2019. Vol. 19, No. 1. pp. 1-11. https://doi.org/10.1186/s12889-019-7460-3

19. Purciel, M. Et Al. Creating and validating GIS measures of urban design for health research. Journal of Environmental Psychology. 2009. Vol. 29 , No. 4, pp. 457-466. https://doi.org/10.1016/j.jenvp.2009.03.004

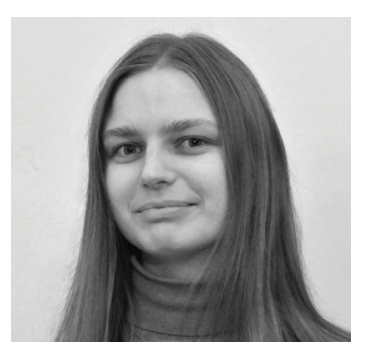

Līva Garkāje is a PhD student of Faculty of Architecture of Riga Technical University. The research topic of her Thesis is Soviet housing architecture in Latvia. In 2016, she obtained a M. Sc. Arch. Degree in 2016, Dipl. Arch degree in 2014 and B. Arch. degree in 2012 from Riga Technical University.

Since 2014, she has been a Researcher and Architect in architecture research and restoration office "Konvents" Ltd. in Riga, Latvia. Her research interests include MoMo architecture heritage history, preservation and revitalisation.

In 2017, she became a member of Docomomo International Latvian Chapter, as well as received a grant of State Culture Capital Foundation (SCCF) for mapping and research of individually designed Soviet housing in Riga, Latvia. In 2015, together with "Konvents" Ltd. she was awarded the 1st place in the competition for the Latvian Cultural Heritage Award 2015 in category "Cultural Heritage Research".

\section{Contact Data}

\section{Līva Garkāje}

E-mail: liva.garkaje@gmail.com 